\title{
Record of American black bear (Ursus americanus) in Durango, Mexico
}

\author{
Jorge Servín ${ }^{*}{ }^{*}$, Dora Carreón-González ${ }^{2}$, Alexis Huerta-García ${ }^{2}$, Floriely Castro-Campos ${ }^{2}$ and Luis F. González-Saravia ${ }^{2}$ \\ ${ }^{1}$ Laboratorio de Ecología y Conservación de Fauna Silvestre, Departamento El Hombre y su Ambiente, Universidad Autónoma \\ Metropolitana Unidad Xochimilco. Calz. Del Hueso 1100, Ciudad de México 04960, México. E-mail jservin@correo.xoc.uam.mx (JS). \\ 2 VISILMEX, A. C. Calz. De la Virgen 3000 Edif. 34-15, Cuidad de México, 04490, México. E-mail: dk mors@hotmail.com (DCG), \\ sixela hg@hotmail.com (AHG), floriely 1405@hotmail.com (FCC), biolgs@yahoo.com (LFGS). \\ ${ }^{*}$ Corresponding author
}

In Mexico, the American black bear (Ursus americanus) has withstood a number of anthropogenic pressures such as habitat loss, illegal poaching, poor legislation regarding conservation, management and exploitation, etc. Consequently, these have been the major causes of the decline of large carnivorous mammals in Mexico. The new technologies currently available have provided tools that facilitate their study, documenting their presence and distribution, in addition to expanding the biological and ecological information of this group of predators. During the 2009 winter season, intensive field surveys were conducted in southeastern Chihuahua and western Durango. In each area surveyed, 40 fixed monitoring stations were set, fitted with a camera trap and an scent station, distributed at distances $\geq 1 \mathrm{~km}$ between stations across the study areas. A total sampling effort of 2,400 days/trap resulted in one record of a juvenile American black bear (Ursus americanus; Figure 1 ) at Ejido "Lobos y Pescaderos", in the municipality of Tepehuanes, Durango, in Sierra Madre Occidental, Mexico (Figure 2). This record was obtained at 2436 masl, representing the second reliable report of the presence of the American black bear at these altitudes. The photographic record currently available underscores the need to implement and intensify long-term surveys that contribute to determine the presence of American black bear in the northwestern states of Mexico, specifically in Sierra Madre Occidental in the state of Durango, in sites already identified as having temperate forests habitat conditions that are potentially suitable for the American black bear.

En México, los osos negros americanos (Ursus americanus) se han enfrentado a diversas presiones antropogénicas como la pérdida de hábitat, cacería ilegal, falta de legislación hacia la conservación, manejo y aprovechamiento, etc., siendo estas las principales causas de disminución de los mamíferos carnívoros de gran talla en México. En la actualidad las nuevas tecnológicas han permitido contar con herramientas que faciliten su estudio, documentar su presencia y distribución, además de incrementar la información biológica y ecológica de este grupo de depredadores. Durante la temporada invernal de 2009 se realizaron prospecciones intensivas de campo en el sureste de Chihuahua y noroeste de Durango. En cada zona de prospección se colocaron 40 estaciones de monitoreo fijas, dotadas de una cámara-trampa y una estación olfativa, distribuidas a distancias $\geq$ a $1 \mathrm{~km}$ entre estaciones en las áreas de estudio. Con un esfuerzo de muestreo total de 2400 días/trampa, se obtuvo el registro de un oso negro americano (Ursus americanus) juvenil (Figura 1), en el Ejido "Lobos y Pescaderos", en el municipio de Tepehuanes, Durango, en la Sierra Madre Occidental de México (Figura 2), el registro se obtuvo a una altitud de $2436 \mathrm{msnm}$, lo que representa el segundo reporte fidedigno de la presencia de oso negro americano a estas altitudes. El presente registro fotográfico hace patente la necesidad de implementar e intensificar prospecciones a largo plazo que contribuyan a conocer la presencia de oso negro americano en los estados del noroeste de México, específicamente en la Sierra Madre Occidental del estado de Durango, sobre todo en aquellas entidades en las que se han identificado las condiciones de hábitat adecuadas de bosques templados y que favorezcan la presencia del oso negro americano.

Key words: black bear; carnivores; Durango; photographic record; México; survey.

(C) 2018 Asociación Mexicana de Mastozoología, www.mastozoologiamexicana.org

\section{Introduction}

The American black bear (Ursus americanus, Pallas, 1780) is the largest carnivorous mammal in Mexican territory. There is incomplete information regarding its geographical distribution in Mexico, partly because this species has disappeared from many areas of its original range (DeflínAlfonso et al. 2011; Juárez-Casillas and Varas 2013; Scheick and McCown, 2014; Monroy-Vilchis et al. 2016). It should be noted that ecological information is even more scarce for black bear populations inhabiting Sierra Madre Occidental, which, according to Hall (1981), belong to two subspecies: U. a. machetes and U. a. amblyceps.

In Mexico, black bear have withstood a number of anthropogenic pressures, the most significant being the decline of wild populations by the end of the decade of 1950 s as a result of campaigns aiming to the extermination of carnivores promoted by the Federal Government (Villa 1960; Baker and Greer 1962). Other factors made the situa- tion worse, such as hunting, habitat loss, and fragmentation caused by the promotion of livestock and agriculture from 1950 across the country (Leopold 1959; Moctezuma and Doan-Crider 2005). Likewise, the social perception of rural communities about large predators, sometimes coupled with the lack of environmental legislation and poor law enforcement, among others, have historically contributed to the few records and lack of robust scientific information about large carnivorous mammals, including the black bear (Delfín-Alfonso et al. 2012; Juárez-Casillas and Varas 2013, Servín 2013). In recent years, the incorporation of new technologies to the study of wildlife, including camera traps, genetic analysis and telemetry, has started to yield reliable data on these mammals, whose unique biological characteristics of large-scale movements and nocturnal habits, as well as low population densities, make them hard to spot, so they frequently go unnoticed in the wild (DelfínAlonso et al. 2011; Juárez-Casillas and Varas 2013; Monroy- 


\section{Vilchis et al. 2016; Camargo-Aguilera et al. 2017).}

Recently, historical and current records on the presence of black bear in Mexico have been reviewed (Deflín-Alfonso et al. 2011; Juárez-Casillas and Varas 2013; Monroy-Vilchis et al. 2016). These reviews found seven records of black bear for the State of Durango, distributed in four municipalities. One record corresponds to the municipality of Canatlan, evidenced by a skin in 1989; four records, to the municipality of Mezquital, through the recovery of one skull and one partial skeleton in 1956 (MSU 817), one stool sample and two cubs captured in 1957; a direct sighting in 2005; one specimen was recorded in the municipality of Ocampo, from a skull in 1903; and, finally, one record was obtained from the municipality of Tepehuanes through direct sighting in 2004 (Baker and Greer 1962; Deflín-Alfonso et al. 2011).

\section{Materials and Methods}

During the winter (22 December to 20 March) of 2009, intensive field surveys were conducted in Sierra Madre Occidental ranging from southwestern Chihuahua to northwestern Durango, in regions covered by well-preserved temperate forests, through camera traps (Wildview ${ }^{\circledR}$ Xtreme4 model). These were distributed at a distance of approximately one kilometer between stations across the study areas, along old roads used for timber extraction, bridle paths, and trails. Each area surveyed included 40 fixed monitoring stations equipped with one camera trap (placed at a height of approximately $50 \mathrm{~cm}$, depending on the characteristics of the land) plus an scent station; bait consisted of sardines in tomato sauce, vanilla extract, and apple. Cameras were operating 24-hours a day for 30 days, capturing 3 images per motion detection event. Sampling effort was calculated by multiplying total number of monitoring stations by total number of sampling days (Chavez et al. 2013).

\section{Results}

A total sampling effort of 2400 days/trap resulted in one record of an American black bear (Ursus americanus) standing upright on its two hind legs; based on body size, it corresponds to a juvenile individual. The animal was photographed at 08:40 hrs on 2 February 2009 (Figure 1), at $25^{\circ}$ $09^{\prime} 45.14^{\prime \prime} \mathrm{N}$ and $105^{\circ} 57^{\prime} 15.90^{\prime \prime} \mathrm{W}$, in pasture land of Ejido "Lobos y Pescaderos", municipality of Tepehuanes, Durango (Figure 2). The record was obtained at 2,436 meters above sea level, representing the second reliable report of the presence of American black bear at these altitudes in the Western Sierra Madre, as the altitudinal distribution of this species ranges between 1,015 and 2,809 masl (DeflínAlfonso et al. 2011). The full identification of the American black bear individual involved an exchange of opinions of specialists, where six observers determined that the images correspond to a black bear.

Based on this record, and given that the specimen photographed is a juvenile, is could not be determined whether this individual belongs to an established population inhabiting the municipality of Tepehuanes or whether it is a juve-

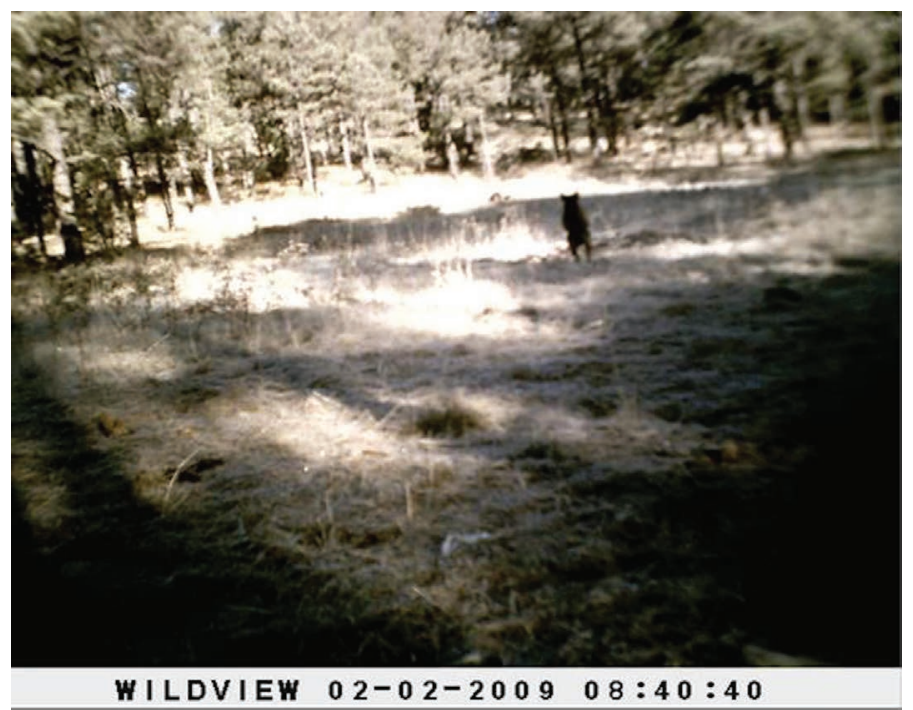

Figura 1. Individuo de oso negro americano (Ursus americanus) fotografiado en los terrenos de agostadero del Ejido "Lobos y Pescaderos", en el Municipio de Tepehuanes, Durango, México

nile individual in a dispersal process. The same camera trap station also recorded the presence of other wildlife species, such as coyote (Canis latrans), white-tailed deer (Odocoileus virginianus), rabbit (Sylvilagus spp.), hare (Lepus californicus), and even creole cattle. There were no further records of $U$. americanus over the course of the survey.

The area where the record was obtained is characterized by pine and pine-oak forest, at an altitude of 2,436 masl. The local climate is temperate, semi-cold with cool and long summer, $\mathrm{Cb}$ (w2), with summer rainfall; precipitation ranges between 873 and 1,200 mm. The maximum temperatures recorded in the area vary between $24^{\circ} \mathrm{C}$ and $34{ }^{\circ} \mathrm{C}$, and the minimum from $-8{ }^{\circ} \mathrm{C}$ to $-16{ }^{\circ} \mathrm{C}$ (INEGI, 2016; Medina et al. 2005). The local topography is mountainous, with areas of gullies to the northwest of the ejido, with elevations ranging from 1,900 to 2,800 masl. in mountainous zones (INEGI, 2016). The study area comprises a broad extension of perennial and intermittent runoff, the latter primarily during the rainy season.

\section{Discussion}

Except for two records, one involving direct sighting in 2004 in Sierra de la Candela, municipality of Tepehuanes, Durango, at 2,809 meters a.s.l. in a pine forest (pers. comm., Jorge I. Servin in Deflín-Alfonso et al. 2011), and one capture in 2014 in the town of Felipe Carrillo Puerto, municipality of Guadalupe Victoria, where it was determined that this individual was dispersing from Sierra Madre Oriental (Camargo-Aguilera et al. 2017), no other recent study had formally reported the presence of American black bear in the State of Durango.

In Mexico, the historical range of the species covered forested regions of northwestern and northeastern States (Leopold 1959; Baker and Greer 1962; Hall 1981). It is currently acknowledged that not all areas within its historical distribution range in Mexico has been properly explored, so that there is a geographic gap regarding its current dis- 


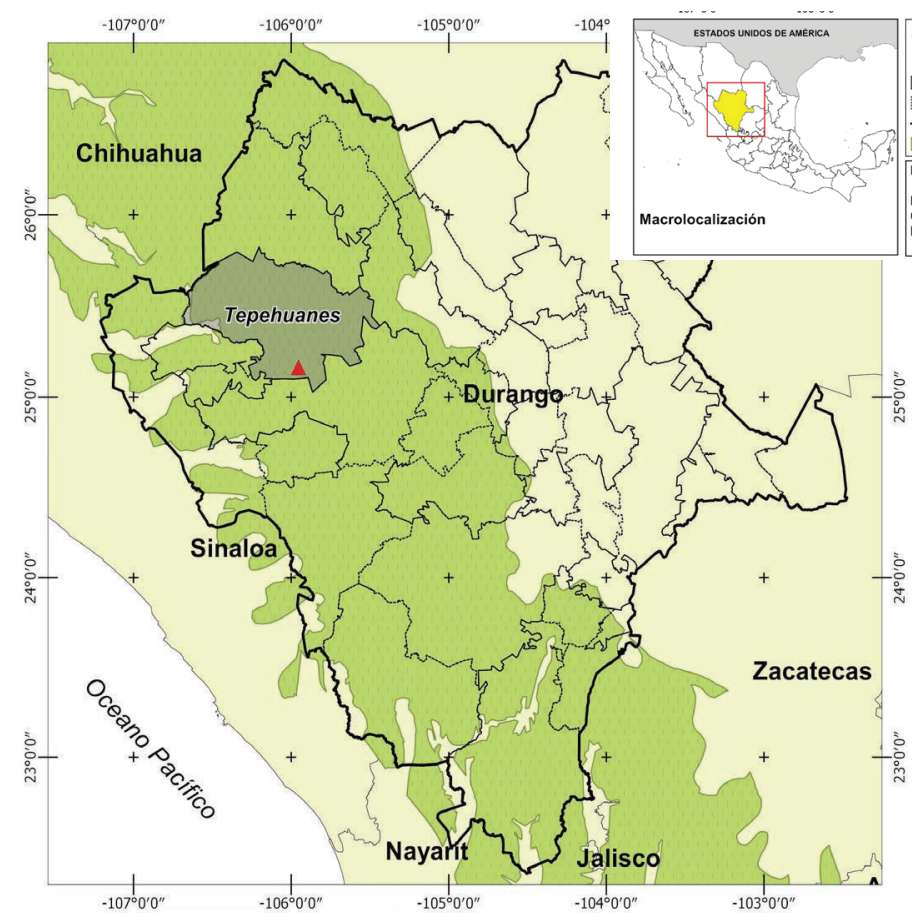

Figura 2. Mapa mostrando el área de estudio en donde se efectuaron las prospecciones en el año 2009, en el Ejido de Lobos y Pescaderos, municipio de Tepehuanes y donde se obtuvo el registro de Oso negro americano (Ursus americanus). Ubicación de la fotocolecta (triangulo rojo). Municipio de Tepehuanes (achurado en gris). División del estado (línea oscura). Sierra madre Occidental (achurado verde).

tribution, mainly in the States of Durango, Aguascalientes and Zacatecas. These gaps, together with insufficient field work aimed at the monitoring of the species, have led to consider $U$. americanus as locally absent or extirpated from these regions (Delfín-Alonso et al. 2011; Monroy-Vilchis et al. 2016).

The present photographic record have determined its presence and underscores the need to implement and intensify field surveys spanning at least one full year, or better still, develop mid- and long-term projects contributing to monitor the presence and even the habitat use and activity patterns of the American black bear in the northwestern regions of Mexico, particularly in the State of Durango on Sierra Madre Occidental. These surveys should be conducted in areas that have been identified as having suitable habitat conditions that favor the presence of this bear as in the municipalities of Guanacevi, Tepehuanes, Topia, Tamazula, Otaez, Santiago Papasquiaro, Durango, Canelas, Pueblo Nuevo, Mezquital and Suchil, just to mention a few.

\section{Acknowledgments}

These field surveys received funding from the following institutions: Universidad Juárez of the State of Durango, Universidad Autónoma Metropolitana, Campus Xochimilco, CONABIO (Project H019), CONANP (2008), VISILMEX (Project 2008-1). We received field support from J. Vizcarra, A. Mendez and staff of UCODEFO, Tepehuanes, Durango. Thanks to C. Rodríguez-Luna for drafting Figure 2. Thanks also to three anonymous reviewers and Juan Pablo Gallo for the recommendations that improved the manuscript. María Elena Sánchez-Salazar translated the manuscript into English.

\section{Literature cited}

BAKER, R. H., AND J. K. Greer. 1962. Mammals of Mexican state of Durango. Publication of the Museum, Michigan State University. Biological Series 2:29-154.

Camargo-Aguilera, M. G., N. E. Lara-Diaz, H. Coronel-Arellano, and C. A. LóPEZ-González. 2017. One black bear (Ursus americanus) connect the great sierras: genetic evidences. Therya 8:277-282.

Chávez, C., A. de la Torre, H. Bárcenas, R. A. Medellín, H. Zarza, and G. Ceballos. 2013. Manual de fototrampeo para estudio de fauna silvestre. El jaguar en México como estudio de caso. Alianza WWF-Telcel, Universidad Nacional Autónoma de México, México.

Delfín-Alfonso, C. A., C. A. López González, and N. E. Lara Díaz. 2011. El Oso negro americano en el Noroeste de México: Recuperación de registros de ocurrencia. Acta Zoológica Mexicana (n. s.) 27:777-801.

Delfín-Alfonso, C. A., C. A. López González, and M. Equihua. 2012. Potential distribution of American black bears in Northwest of Mexico and implications for their conservation. Ursus 23:65-77.

HALL, E. R. 1981. The mammals of North America. John Wiley and Sons. New York, U. S. A.

Instituto Nacional de Estadística y Geografía (INEGI). 2016. Anuario estadístico y geográfico de Durango. México.

JuÁREZ-CASILLAS, L. A., AND C. VARAS. 2013. Black bears in Mexico, an update of literature review. Therya 4:447-465.

LeOpold, A. S. 1959. Wildlife of Mexico. Berkeley and Los Ángeles. University of California Press. Berkeley, U. S. A.

Medina, G., G. Díaz, J. López, J. A. Ruiz, and M. M. Marín. 2005. Estadísticas climatológicas básicas del estado de Durango (período 1961-2003). Libro Técnico 1. INIFAP. Ciudad de México, México.

Moctezuma-Orozco, O., and D. L. Doan-Crider. 2005. Oso negro americano. Pp. 419-422 in Los mamíferos silvestres de México (Ceballos G., and G. Oliva, eds.). Comisión Nacional para el Conocimiento y Uso de la Biodiversidad. Fondo de Cultura Económica. Ciudad de México, México.

Monroy-Vilchis, O., Castillo-Huitron, N. M., Zarco-González, M. M., AND Rodriguez-Soto, C. 2016. Potential distribution of Ursus americanus in Mexico and its persistence: Implication for conservation. Journal for Nature Conservation 29:62-68.

Servín, J. 2013. Perspectivas de estudio, conservación y manejo de los Carnívoros en México. Therya 4:327-330.

Secretaría del Medio Ambiente y Recursos Naturales (SEmarnat). 2010. Norma Oficial Mexicana NOM-059-SEMARNAT-2010. Protección ambiental-Especies nativas de México de flora y fauna silvestres-Categorías de riesgo especificaciones para su inclusión, exclusión o cambio-lista de especies en riesgo. Ciudad de México, México.

SCHEICK, B. K., AND W. McCown. 2014. Geographic distribution of American black bears in North America. Ursus 25: 24-33.

VILLA, B. 1960. Combate contra lobos y coyotes del Norte de México. Anales del Instituto de Biología 31:463-499.

Associated editor: Pablo Teta

Submitted: November 19, 2017; Reviewed: January 10, 2018;

Accepted:September 2, 2018; Published on line: September 27, 2018. 
RECORD OF AMERICAN BLACK BEAR, DURANGO, MEXICO.

264 THERYA Vol. 9 (3): 261-264 